\title{
Fresh and residual phosphorus uptake by ryegrass from soils with different fertilization histories
}

\section{Journal Article}

\section{Author(s):}

Oberson, Astrid; Tagmann, Hans U.; Langmeier, Monika; Dubois, David; Mäder, Paul; Frossard, Emmanuel

Publication date:

2010-09

Permanent link:

https://doi.org/10.3929/ethz-b-000157691

\section{Rights / license:}

In Copyright - Non-Commercial Use Permitted

Originally published in:

Plant and Soil 334(1-2), https://doi.org/10.1007/s11104-010-0390-6 


\title{
Fresh and residual phosphorus uptake by ryegrass from soils with different fertilization histories
}

\author{
Astrid Oberson - Hans U. Tagmann • \\ Monika Langmeier • David Dubois • Paul Mäder • \\ Emmanuel Frossard
}

Received: 30 October 2009 / Accepted: 12 April 2010/Published online: 30 April 2010

(C) Springer Science+Business Media B.V. 2010

\begin{abstract}
Organic farming largely depends on animal manure as a source of phosphorus $(\mathrm{P})$ and the recycling of animal manure globally is becoming increasingly important. In a pot experiment, using radioactive $\mathrm{P}$ labeling techniques, we studied ryegrass uptake of $\mathrm{P}$ applied with animal manure and water soluble mineral fertilizer to soils that had been cropped for 22 years according to organic or conventional farming practices. The soils differed in $\mathrm{P}$ status and microbial activity. Labeling soil-available $\mathrm{P}$ also allowed assessing the uptake from residual $\mathrm{P}$ that remained in the soils because of their different fertilization histories. On each soil, recovery of fresh manure $\mathrm{P}$ in four harvests of ryegrass shoots was lower than recovery of mineral P. It ranged from $24 \%$ to $35 \%$ for manure $\mathrm{P}$ and from $37 \%$ to $43 \%$ for
\end{abstract}

Responsible Editor: N. Jim Barrow.

A. Oberson $(\bowtie) \cdot$ H. U. Tagmann $\cdot$ M. Langmeier

E. Frossard

Institute of Plant, Animal and Agroecosystem Sciences,

Group of Plant Nutrition, Research Station Eschikon,

ETH Zurich,

Lindau, Switzerland

e-mail: astrid.oberson@ipw.agrl.ethz.ch

D. Dubois

Research Station Agroscope Reckenholz-Tänikon (ART),

Zurich, Switzerland

P. Mäder

Research Institute of Organic Agriculture (FiBL),

Frick, Switzerland mineral P. Recovery of fresh manure $\mathrm{P}$ was affected by soil-available $\mathrm{P}$ contents. It was lower at a higher available $\mathrm{P}$ in a conventional soil. Different levels in microbial activity among soils were of lesser importance for the recovery of fresh manure $\mathrm{P}$ in plants. The recovery of residual $P$ ranged from $9 \%$ to $15 \%$. Residual $\mathrm{P}$ contained in organic cropped soils contributed less to $\mathrm{P}$ nutrition of ryegrass than the residual $\mathrm{P}$ contained in conventional cropped soils, probably due to their lower residual $\mathrm{P}$ contents being composed of stable $\mathrm{P}$ forms. The indirect isotope dilution technique is useful in assessing manure $\mathrm{P}$ uptake by plants, but attention must be given to added $\mathrm{P}$ interactions, i.e., the potential impact of organic amendments on $\mathrm{P}$ uptake from nonlabeled soil and residual $\mathrm{P}$.

Keywords Phosphorus - Animal manure $\cdot$ Residual phosphorus · Isotope techniques · Phosphorus uptake . Organic and conventional farming

\section{Introduction}

The efficient recycling of phosphorus (P) in animal manure is crucial for the efficient use of a scarce resource in agricultural production (Stewart et al. 2005) and for the protection of the environment (Hooda et al. 2001). Organic farming systems largely depend on organic P sources (Oberson and Frossard 2005) and the recycling of nutrients contained in animal manure is of major importance for mixed 
crop-livestock farms. Manure $\mathrm{P}$ is composed of inorganic and organic forms (Toor et al. 2006). After application to the soil, these compounds undergo abiotic and biotic reactions which determine the availability of manure $\mathrm{P}$ to crops. Freshly applied manure $\mathrm{P}$ not taken up by a crop remains in inorganic and organic $\mathrm{P}$ pools in the soil (Guggenberger et al. 2000; Sharpley et al. 1984) and can become available for later crops. In contrast to residual $\mathrm{P}$ uptake by plants after mineral fertilizer application (Barrow 1980), the uptake of residual $P$ after manure application has been hardly investigated and, until now, never using isotope techniques.

Crop P uptake from fertilizers can be assessed using direct or indirect $\mathrm{P}$ radioisotope labeling techniques (Gallet et al. 2003; Morel and Fardeau 1989a). The direct tracer approach measures the proportion of $\mathrm{P}$ in the plant derived from the labeled fertilizer by comparing the specific activity (SA) of the plant with the SA of the fertilizer, the SA being the ratio between radioactive $\mathrm{P}$ and total $\mathrm{P}$. This direct approach cannot be applied to $\mathrm{P}$ amendments such as animal manure. In these cases an indirect isotope dilution approach is used where the plant available soil $\mathrm{P}$ is labeled (Frossard et al. 1996; Sinaj et al. 2002). This approach is based on the assumption that the soil-available $\mathrm{P}$ pool can be homogenously labeled. The proportion of $\mathrm{P}$ in the plant derived from the fertilizer can then be determined using isotopic dilution principles, i.e. by comparing the SA of plants grown on the same, radioactive P-labeled soil, with or without freshly applied non-labeled fertilizer. This approach has been successfully used to determine the recovery of freshly applied mineral fertilizer P (Fardeau 1996), but not yet for animal manure. The effects of the greater microbial activity induced by fresh manure addition (Wichern et al. 2004) on the indirect method have not yet been addressed.

Because of the short half-life times of $\mathrm{P}$ radioisotopes, residual $\mathrm{P}$ cannot be labeled and the $\mathrm{P}$ uptake from residual $\mathrm{P}$ can only be determined by the indirect isotope dilution approach (Morel and Fardeau 1989a). The dilution of the SA of plants growing on a regularly $\mathrm{P}$ fertilized soil, compared to the SA of plants growing on the non-fertilized control soil, is attributed to P derived from residual $\mathrm{P}$. This approach only applies to field experiments with $\mathrm{P}$ fertilized treatments and a nonfertilized control run over several years. Residual $\mathrm{P}$ is operationally defined by the difference in total $\mathrm{P}$ content between the non-fertilized and fertilized soil (Morel and Fardeau 1989a). Residual P is composed of plant-available soil $\mathrm{P}$ depleted in the non-fertilized soil but not in the fertilized soils and of residual fertilizer $\mathrm{P}$ remaining in the fertilized soils. The recovery of residual $\mathrm{P}$ is calculated by dividing residual $\mathrm{P}$ uptake by the total residual $\mathrm{P}$ present in the soil.

In 1978, a long term experiment started in Switzerland to study the effect of organic and conventional cropping systems on crop performance and soil fertility (Mäder et al. 2002). The studied systems differ in the amounts and forms of $\mathrm{P}$ inputs. The organic systems receive $\mathrm{P}$ inputs in the form of animal manure. Conventional systems are fertilized either with animal manure plus water-soluble mineral P, or by water-soluble P alone. Several studies have demonstrated the impact of the cropping systems on aspects of the $\mathrm{P}$ cycle. The higher microbial activity of organically cropped soils against that of the conventionally cropped soil receiving only mineral fertilizers resulted in a larger microbial $\mathrm{P}$ pool and a higher mineralization of soil organic P (Oehl et al. 2001, 2004). On the other hand, during the course of the field experiment, total and available $\mathrm{P}$ contents decreased more in soils of organic than conventional systems, mostly because of their P deficit in P balances (Oehl et al. 2002). (Mäder et al. 2002) suggested that the higher soil microbiological activity and higher biodiversity found in organic plots may render these systems less dependent on external inputs, i.e. result in more efficient nutrient use.

Using $\mathrm{P}$ radioisotope techniques, we investigated whether long-term organic vs. conventional cropping has an effect on the ryegrass uptake from freshly applied animal manure and water soluble mineral $\mathrm{P}$ fertilizers and from residual $\mathrm{P}$. We tested the hypotheses that i) uptake from freshly applied manure P by ryegrass is higher on soils from organic than conventional cropping systems because of their greater microbial activity and lower available $\mathrm{P}$, and ii) that lower uptake from freshly applied manure rather than mineral $\mathrm{P}$ is compensated by a higher uptake from residual $\mathrm{P}$ on soils fertilized with manure. We carried out a pot experiment growing Italian ryegrass (Lolium multiflorum) on soils taken from the different cropping systems of the field experiment. We compared the $\mathrm{P}$ uptake in four harvests of ryegrass from animal manure $\mathrm{P}$ or mineral fertilizer 
P freshly applied to each soil. In addition, we determined the uptake by ryegrass of residual $\mathrm{P}$ related to the soils' different $\mathrm{P}$ fertilization histories prior to the soil collection for our growth experiment.

\section{Material and methods}

\section{Cropping systems and soils}

Soil samples were taken from the long-term "DOK" field experiment located at Therwil near Basle (Switzerland) established on a loamy silt Typic Hapludalf (USDA 1999) developed on loess in a temperate climate. The topsoil layer contains $12 \%$ sand, $72 \%$ silt and $16 \%$ clay (Leifeld et al. 2009). The field experiment is being carried out by Agroscope Reckenholz-Tänikon and the Research Institute of Organic Agriculture, Frick, Switzerland. The conception and experimental design of the field experiment, including a detailed description of the management practices, were presented by (Besson and Niggli 1991) and by (Mäder et al. 2002). Since 1978, two organic and two conventional cropping systems have been compared. All treatments are cultivated in four replicates in the field with the same seven-year crop rotation in a latin square split-split-plot design. The systems differ mainly in fertilization and plant protection (Table 1). Soils were sampled at the end of the vegetation period in November 1999 from the bio-dynamic (BIODYN), the bio-organic (BIOORG), a conventional system receiving mineral fertilizer and animal manure (CONFYM), a conventional system receiving exclusively mineral fertilizers (CONMIN) and a non-fertilized control (NOFERT). All fertilized treatments included in our study receive amounts and forms of nutrient inputs which are typical for the respective farming system in Switzerland. The slurries and farmyard manures originate from farms which are managed according to the respective system. They are also stored and prepared on the farms as indicated in Table 1. The average $\mathrm{P}$ fertilization and $\mathrm{P}$ balances are summarized in Table 1. Selected chemical soil characteristics with emphasis on $\mathrm{P}$ status are shown in Table 2. Subsequently we group soils from BIODYN, BIOORG, CONFYM and CONMIN, all of which were regularly fertilized, as FERT soils, in contrast to the NOFERT control which received no fertilizer.
Topsoil samples $(0-18 \mathrm{~cm})$ were taken with an auger (diameter $2.5 \mathrm{~cm}$, Eijkelkamp, Netherlands) from four replicate plots per cropping system. Per plot of $100 \mathrm{~m}^{2}$ size $(5 \mathrm{~m}$ width $\times 20 \mathrm{~m}$ length) 90 cores were taken and pooled into a composite sample. At the time of sampling, plots were planted with a 15-month old grass-clover meadow. Field moist soils were sieved at $5 \mathrm{~mm}$ and stored at $4^{\circ} \mathrm{C}$ for 10 weeks.

Plant growth experiment and plant analyses

For the plant growth experiment, soil from the four replicate plots of the same treatment was pooled and pre-incubated at $44 \%$ water-holding capacity $(235 \mathrm{~g}$ $\mathrm{H}_{2} \mathrm{O} \cdot \mathrm{kg}^{-1}$ soil dry matter), $20^{\circ} \mathrm{C}$ and $80-85 \%$ atmospheric humidity for 2 weeks before the start of the plant growth experiment. Four treatments were applied to each soil in a completely randomized design with four replicates. Soils were either given no fresh P (zero P) or an application of either animal manure $\mathrm{P}$ (manure $\mathrm{P}$ ) or water-soluble mineral $\mathrm{P}$ which was either not labeled with radioactive $\mathrm{P}$ (mineral P) or labeled (mineral P33). Animal manure was cow feces collected from a cow exclusively fed on hay as described in (Langmeier et al. 2002). Manure characteristics are shown in Table 3. Mineral $\mathrm{P}$ was applied in the form of water-soluble diammonium phosphate (salt at reagent grade for analytical use).

For the zero $\mathrm{P}$, mineral $\mathrm{P}$ and manure $\mathrm{P}$ treatments, soil isotopically exchangeable $\mathrm{P}$ was labeled by carefully mixing soil and a solution containing carrier-free ${ }^{33} \mathrm{P}$-orthophosphate at a rate of $1.9 \mathrm{MBq} \mathrm{kg}{ }^{-1}$ soil. Then the fertilizer, i.e., diammonium phosphate solution or manure $\mathrm{P}$ (also dissolved in a suspension to facilitate homogenous distribution) was added at a rate of $30 \mathrm{mg} \mathrm{P} \mathrm{kg}^{-1}$ soil dry matter and carefully mixed into the soil. The mineral P33 treatment was obtained by adding a ${ }^{33} \mathrm{P}$-orthophosphate labeled diammonium phosphate solution also at a rate of $30 \mathrm{mg} \mathrm{P} \mathrm{kg}^{-1}$ soil and $1.6 \mathrm{MBq} \mathrm{kg}^{-1}$ soil. Then P-free nutrient solutions containing macro- and micronutrients were added by taking into account the rates of nutrients applied with the P fertilizers (i.e. total $\mathrm{N}, \mathrm{K}, \mathrm{Ca}$ and $\mathrm{Mg}$ applied with manure; $\mathrm{N}$ applied with diammonium phosphate). The final same levels in all treatments were $\left(\mathrm{mg} \mathrm{kg}^{-1}\right.$ soil): $100 \mathrm{~N}, 200 \mathrm{~K}, 35 \mathrm{Ca}$ and $16 \mathrm{Mg}$. Microelements were added to all treatments at ( $\mathrm{mg} \mathrm{kg}^{-1}$ soil): $2 \mathrm{Cu}, 2$ 
Table 1 Fertilization and plant protection in the organic and conventional cropping systems and in the unfertilized control of the longterm field experiment, with average $\mathrm{P}$ input and $\mathrm{P}$ balances for 21 years

\begin{tabular}{|c|c|c|c|c|c|}
\hline & \multirow{2}{*}{$\begin{array}{l}\text { Control } \\
\text { NOFERT }\end{array}$} & \multicolumn{2}{|c|}{ Organic systems } & \multicolumn{2}{|c|}{ Conventional systems $\mathrm{s}^{\mathrm{a}}$} \\
\hline & & BIODYN & BIOORG & CONFYM & CONMIN $^{\mathrm{b}}$ \\
\hline & $\begin{array}{l}\text { Unfertilized } \\
\text { control }\end{array}$ & Bio-dynamic & Bio-organic & $\begin{array}{l}\text { Conventional with } \\
\text { manure }\end{array}$ & $\begin{array}{l}\text { Conventional, exclusively } \\
\text { mineral fertilizers }\end{array}$ \\
\hline $\begin{array}{l}\text { Fertilization: } \\
\text { Type and level }\end{array}$ & None & $\begin{array}{l}\text { Composted farmyard } \\
\text { manure (FYM), aerated } \\
\text { slurry from 1.2/1.4 LU } \\
\text { ha }^{-1} \mathrm{yr}^{-1 \mathrm{c}}, \text { preparations }^{\mathrm{d}}\end{array}$ & $\begin{array}{c}\text { Slightly rotted manure } \\
\text { and aerated slurry } \\
\text { from } 1.2 / 1.4 \mathrm{LU} \mathrm{ha}{ }^{-1} \\
\mathrm{yr}^{-1} \mathrm{ce}\end{array}$ & $\begin{array}{l}\text { Manure, slurry and } \\
\text { complement of mineral } \\
\text { fertilizer according to } \\
\text { official guidelines }\end{array}$ & $\begin{array}{l}\text { Mineral fertilizer } \\
\text { according to official } \\
\text { guidelines }\end{array}$ \\
\hline P fertilization & 0 & 24 & 27 & $\begin{array}{l}\text { official guidelines } \\
43\end{array}$ & $28^{\mathrm{f}}(41)$ \\
\hline \multicolumn{6}{|l|}{$\mathrm{kg}^{-1} \mathrm{ha}^{-1} \mathrm{yr}^{-1}$} \\
\hline $\mathrm{P}$ balance & -21 & -8 & -6 & +4 & $-5^{f}(+6)$ \\
\hline \multicolumn{6}{|l|}{$\mathrm{kg}^{-1} \mathrm{ha}^{-1} \mathrm{yr}^{-1}$} \\
\hline \multicolumn{6}{|l|}{ Plant protection } \\
\hline \multicolumn{4}{|l|}{ Weed control } & \multirow{2}{*}{\multicolumn{2}{|c|}{$\begin{array}{l}- \text { Mechanical and herbicides }- \\
\text { Fungicides (thresholds) }\end{array}$}} \\
\hline Disease control & \multicolumn{2}{|c|}{ Indirect methods } & \multirow{2}{*}{$\begin{array}{l}\text { Indirect methods, until } \\
1991 \text { copper } \\
\text { ntrol }\end{array}$} & & \\
\hline Insect control & 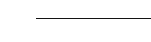 & Plant extracts, bio-cc & & Insecticide & s (thresholds) \\
\hline Special treatments & Bio-dy & namic preparations ${ }^{\mathrm{g}}$ & None & - Plant grov & th regulators \\
\hline
\end{tabular}

${ }^{\text {a }}$ Conventional in the 1st crop rotation period from 1978 to 1984 . In the text, CONFYM and CONMIN are referred to consistently as conventional systems, although they have been managed as integrated systems since 1985

${ }^{\mathrm{b}} \mathrm{CONMIN}$ was unfertilized in the 1 st crop rotation period from 1978 to 1984

${ }^{\mathrm{c}}$ Increase from 1.2 to 1.4 livestock units (LU) ha ${ }^{-1} \mathrm{yr}^{-1}$ at the beginning of the 3rd crop rotation period (1992 to 1998)

${ }^{\mathrm{d}}$ Biodynamic composting additive (Mäder et al. 2002)

${ }^{\mathrm{e}}$ From 1978 till 1991 about 14\% of $\mathrm{P}$ input was applied in form of rock phosphate

${ }^{\mathrm{f}}$ Average for three crop rotations because also non fertilized 1st crop rotation relevant for P status comparison; in brackets average of second and third crop rotation

${ }^{\mathrm{g}}$ Biodynamic preparations to strengthen plant resistance to pests and diseases, and for the promotion of plant growth and development (Besson and Niggli 1991; Mäder et al. 2002)

Mn, $1 \mathrm{Zn}, 1 \mathrm{~B}$ and 0.1 Mo. Portions of labeled soil corresponding to $900 \mathrm{~g}$ dry soil were placed into pots. Each pot was sown with $0.9 \mathrm{~g}$ seeds of Italian ryegrass (Lolium multiflorum, var. Axis) and placed in a growth chamber $(70 \%$ atmospheric humidity, photoperiod $16 \mathrm{~h}$ day $^{-1}$, temperature $24^{\circ} \mathrm{C}$, and $18^{\circ} \mathrm{C}$ for day and night, respectively). Soil moisture was controlled by weighing and was readjusted to $60 \%$ of the total waterholding capacity throughout the experiment by daily watering. The ryegrass was cut 17 days, 31 days, 45 days and 59 days after sowing at $2 \mathrm{~cm}$ above the ground. After the first, second and third harvest, N, K,
Table 2 Selected characteristics and $\mathrm{P}$ status of the soils (average and standard error)

\footnotetext{
${ }^{\mathrm{a}}$ For explanations of acronyms for soils see Table 1
}

\begin{tabular}{lccccr}
\hline Soils $^{\mathrm{a}}$ & NOFERT & BIODYN & BIOORG & CONFYM & CONMIN \\
\hline $\mathrm{pH}\left(\mathrm{H}_{2} \mathrm{O}\right)$ & $5.5(0.1)$ & $6.4(0.1)$ & $6.0(0.1)$ & $6.1(0.1)$ & $5.6(0.1)$ \\
Organic C $\left(\mathrm{g} \mathrm{kg}^{-1}\right)$ & $12.6(1.4)$ & $14.7(0.3)$ & $13.1(1.3)$ & $12.6(0.3)$ & $13.2(1.4)$ \\
Total P $\left(\mathrm{mg} \mathrm{kg}^{-1}\right)$ & $563(11)$ & $640(2)$ & $629(1)$ & $683(1)$ & $658(1)$ \\
$\begin{array}{l}\text { Inorganic P } \\
\left(\mathrm{mg} \mathrm{kg}^{-1}\right)\end{array}$ & $224(4)$ & $261(2)$ & $264(2)$ & $331(3)$ & $309(2)$ \\
Organic P $\left(\mathrm{mg} \mathrm{kg}^{-1}\right)$ & $339(15)$ & $379(4)$ & $364(2)$ & $352(4)$ & $349(3)$ \\
\hline
\end{tabular}


Table 3 Forms and exchangeability of manure $\mathrm{P}$, and total $\mathrm{N}$ and $\mathrm{C}$ concentration of manure

\begin{tabular}{|c|c|c|c|c|c|c|c|}
\hline \multirow{2}{*}{$\begin{array}{l}\text { Total P } \\
\mathrm{g} \mathrm{kg}^{-1} \text { dry wt }\end{array}$} & \multirow[t]{2}{*}{ Total organic P } & \multirow[t]{2}{*}{ Total inorganic $\mathrm{P}$} & \multicolumn{3}{|c|}{ Exchangeable $\mathrm{P}^{\mathrm{a}}$} & \multirow{2}{*}{$\begin{array}{l}\text { Total N } \\
\mathrm{g} \mathrm{kg}^{-1} \text { dry }\end{array}$} & \multirow[t]{2}{*}{ Total C } \\
\hline & & & \multicolumn{3}{|c|}{$\%$ of inorganic $\mathrm{P}$} & & \\
\hline $12.4(2.0)$ & $3.3(0.5)$ & $9.0(1.9)$ & $56(1)$ & $11(2.9)$ & $32(1.7)$ & $25.3(0.6)$ & $423(0.3)$ \\
\hline
\end{tabular}

Average and standard deviation of three analytical replicates

$\mathrm{E} 1 \mathrm{~min}=\mathrm{P}$ exchangeable within first minute of isotopic exchange; E1min-3 months $=\mathrm{P}$ exchangeable during 3 months, and $\mathrm{E}>3$ months exchangeable after more than 3 months time

${ }^{a}$ Determined by isotopic exchange kinetics method (Fardeau 1993) using $1 \mathrm{~g}$ feces dry matter and $99 \mathrm{ml}$ distilled water

$\mathrm{Ca}$ and $\mathrm{Mg}$ were applied at the rate of (in $\mathrm{mg} \mathrm{kg}^{-1}$ soil) $110 \mathrm{~N}, 90 \mathrm{~K}, 20 \mathrm{Ca}, 5 \mathrm{Mg}$.

After each harvest, the dry matter yield of aerial parts was weighed and the SA in the plant material determined. About $400 \mathrm{mg}$ of finely cut plant material was ashed at $550^{\circ} \mathrm{C}$ for $4 \mathrm{~h}$. Phosphorus in the plant material was determined after dissolving the ashes in $2 \mathrm{ml}$ of $20 \% \mathrm{HCl}$. After heating, the solution was filtered and diluted to a final volume of $50 \mathrm{ml}$. Total $\mathrm{P}$ was measured by the method of (Murphy and Riley 1962). Radioactivity was measured by scintillation counting after mixing $1 \mathrm{ml}$ of extract with $5 \mathrm{ml}$ of scintillation liquid (Ultima Gold $\mathrm{AB}$, Packard Instrument Co.). The values were corrected for radioactive decay back to the day of labeling (corrected radioactivity, $\mathrm{r}$ ). Total $\mathrm{N}$ concentration was analysed using a Carlo Erba flash combustion CN-analyzer (NA1500) (Carlo Erba, Milano, Italy).

Soil incubation experiment and soil analyses

Soils were amended with the zero $\mathrm{P}$, mineral $\mathrm{P}$ and manure $P$ treatments, at four replicates per soilfertilizer treatment combination. The same initial macro- and micronutrient doses were added as used for the plant growth experiment. Soils were then incubated at $60 \%$ water holding capacity under the identical experimental conditions as the plant growth experiment. The treatment mineral P33 was not included as it is identical to mineral P. Moist soil samples taken 4 days after fertilizer addition were analyzed for $\mathrm{P}$ status and $\mathrm{pH}$. Water extractable $\mathrm{P}$ was determined in a 1:10 soil:water suspension shaken for $16 \mathrm{~h}$ (Fardeau 1993). The $\mathrm{pH}$ of the amended soils was measured in a 1:2.5 soil water suspension. Microbial $\mathrm{P}$ was determined after 8 days of incubation using the fumigation-extraction method described in (Oehl et al. 2001). Total P, inorganic and organic contents in soils of the zero $\mathrm{P}$ treatment were determined with the ignition method of (Saunders and Williams 1955). In this method organic $P$ obtained was the difference between total P extracted from an ignited sample and inorganic $\mathrm{P}$ extracted from the non ignited sample, the extractant being $0.5 \mathrm{M}$ sulfuric acid. Residual $\mathrm{P}$ was calculated as the difference between total $\mathrm{P}$ in a FERT minus total $\mathrm{P}$ in the NOFERT soil.

Calculation of $\mathrm{P}$ uptake by ryegrass from different sources

The $\mathrm{P}$ taken up by the ryegrass is composed of $\mathrm{P}$ derived from i) freshly applied fertilizer (mineral $\mathrm{P}$ or manure $\mathrm{P}$ ) at the beginning of the plant growth experiment; ii) residual $\mathrm{P}$ (composed of plantavailable soil $P$ that has been depleted in the NOFERT soil but not in the FERT soils and of residual fertilizer $\mathrm{P}$ remaining in the FERT soils) and iii) native soil $\mathrm{P}$. Phosphorus uptake by ryegrass from seeds during growth cycles one and two was accounted for (see below). The principles and derivation of the formulas to calculate $P$ in the plant derived from fresh fertilizers and residual $\mathrm{P}$ were originally presented by (Morel and Fardeau 1989a; Morel and Fardeau 1989b) and have recently been reported in detail by (Gallet et al. 2003). Therefore, we only present the final formulas here.

\section{Uptake of $P$ from fresh fertilizer}

The fraction (Pdff\%, in \%) of $\mathrm{P}$ in the plant that is derived from the freshly applied fertilizer $\mathrm{P}$ when 
using a labeled fertilizer (mineral P33) for any soil (FERT or NOFERT) is:

$\mathrm{Pdff} \%=100 \times\left(\mathrm{SA}_{\text {plmineralP33 }}\right) /\left(\mathrm{SA}_{\text {mineralP33 }}\right)$

With:

$\mathrm{SA}_{\text {plmineralP33 }} \mathrm{SA}$ of $\mathrm{P}$ in plants grown with freshly applied ${ }^{33} \mathrm{P}$ labeled diammonium phosphate $\left(\mathrm{kBq} \mathrm{mg}^{-1} \mathrm{P}\right)$

$\mathrm{SA}_{\text {mineralP33 }} \mathrm{SA}$ of applied fresh diammonium phosphate $\left(\mathrm{kBq} \mathrm{mg}^{-1} \mathrm{P}\right)$

The amount of fresh fertilizer taken up by the plants (Pdff, $\mathrm{mg} \mathrm{kg}^{-1}$ soil) is:

Pdff $=$ Pdff $\% \times$ Pupt $/ 100$

With

Pupt $\quad \mathrm{P}$ taken up by the plants $\left(\mathrm{mg} \mathrm{kg}^{-1}\right.$ soil)

The fraction (\%) of $\mathrm{P}$ in the plant that is derived from the fresh fertilizer when applying non-labeled fertilizer (either mineral $\mathrm{P}$ or manure $\mathrm{P}$ ) to a soil where plant available $\mathrm{P}$ has been labeled is:

$\mathrm{Pdff} \%=100 \times\left(1-\mathrm{SA}_{\mathrm{pl}+\mathrm{P}} / \mathrm{SA}_{\mathrm{plzeroP}}\right)$

With

$\mathrm{SA}_{\mathrm{pl}+\mathrm{P}} \quad \mathrm{SA}$ in plants grown with fresh fertilizer $\left(\mathrm{kBq} \mathrm{mg}^{-1} \mathrm{P}\right)$

$\mathrm{SA}_{\text {plzerop }} \mathrm{SA}$ in plants grown on the same soil without fresh fertilizer $\left(\mathrm{kBq} \mathrm{mg}^{-1} \mathrm{P}\right)$

The amount of fresh fertilizer taken up by the plants is calculated using Eq. 2. The recovery of fresh fertilizer $\mathrm{P}$ in plants (RecPff\%, in \%) is:

RecPff $\%=100 \times$ Pdff $/ F$

With

F amount of freshly applied P fertilizer (30 mg P $\mathrm{kg}^{-1}$ soil for mineral P33, mineral $\mathrm{P}$ and manure $\mathrm{P}$, respectively).

\section{Uptake of residual $P$}

The fraction (Pdrf\%, in \%) of $\mathrm{P}$ in the plant that is derived from residual $\mathrm{P}$ is obtained by comparing the SA of plants grown on any of the FERT soils with the SA of plants grown in absence of residual $P$ (NOFERT), after labeling soil available $\mathrm{P}$ with carrier-free ${ }^{33} \mathrm{P}$-orthophosphate (Morel and Fardeau 1989a):

$\mathrm{Pdrf} \%=100 \times\left(1-\mathrm{SA}_{\text {plFERTzeroP }} / \mathrm{SA}_{\text {plNOFERTzeroP }}\right)$

With

$\operatorname{Pdrf} \%$

$\mathrm{SA}_{\text {plFERTzeroP }}$

fraction (\%) of $\mathrm{P}$ in plant derived from residual $\mathrm{P}$

containing residual $P$ but no fresh $\mathrm{P}$ fertilizer $\left(\mathrm{kBq} \mathrm{mg}^{-1} \mathrm{P}\right)$

$\mathrm{SA}_{\text {pINOFERTzerop }} \mathrm{SA}$ in plants grown on NOFERT soil containing no residual $\mathrm{P}$ and no fresh $\mathrm{P}$ fertilizer $\left(\mathrm{kBq} \mathrm{mg}^{-1} \mathrm{P}\right)$

The Pdrf(\%) can also be obtained with fresh $\mathrm{P}$ fertilizer application. The SA of plants grown on any of the FERT soils is compared to SA of plants grown in the absence of residual P (NOFERT), for each application of fresh fertilizer. Equation [6] applies for manure $\mathrm{P}$ and mineral $\mathrm{P}$ where soil available $\mathrm{P}$ has been labeled with carrier-free ${ }^{33} \mathrm{P}$ orthophosphate and for mineral P33 where the labeled mineral P fertilizer has been added (Gallet et al. 2003; Morel and Fardeau 1989a; Morel and Fardeau 1989b):

$\mathrm{Pdrf} \%=100 \times\left(1-\mathrm{SA}_{\mathrm{plFERTfP}} / \mathrm{SA}_{\mathrm{plNOFERTfP}}\right)$

With

$\mathrm{SA}_{\text {plFERTfP }} \quad \mathrm{SA}$ in plants grown in FERT soils containing residual $\mathrm{P}$ and fresh $\mathrm{P}$ fertilizer $\left(\mathrm{kBq} \mathrm{mg}^{-1} \mathrm{P}\right)$

$\mathrm{SA}_{\text {pINOFERTfP }} \mathrm{SA}$ in plants grown on NOFERT soil containing no residual $\mathrm{P}$ but fresh fertilizer $\left(\mathrm{kBq} \mathrm{mg}{ }^{-1} \mathrm{P}\right)$

The amount of residual $\mathrm{P}$ (Pdrf, $\mathrm{mg} \mathrm{kg}^{-1}$ soil) taken up by the plants is:

Pdrf $=$ Pdrf $\% \times$ Pupt $/ 100$

The recovery of residual $\mathrm{P}(\mathrm{RecPrf} \%)$ in plants is:

$\operatorname{RecPrf} \%=100 \times \operatorname{Pdrf} /($ PtotFERT - PtotNOFERT $)$

With

PtotFERT total $\mathrm{P}$ content in soil FERT (mg $\mathrm{P} \mathrm{kg}^{-1}$ soil)

PtotNOFERT total $\mathrm{P}$ content in soil NOFERT (mg $\mathrm{P} \mathrm{kg}^{-1}$ soil). 
The Pdff and Pdrf were calculated for each single harvest and totaled to obtain the total Pdff and Pdrf, respectively, over four harvests. The totals of Pdff and Pdrf, were used to calculate the respective recoveries in four harvests.

\section{$P$ derived from the seeds and from the soil}

Phosphorus taken up from ryegrass seeds is an additional source (Pdfseed) that has to be accounted for, particularly in soils with low plant available $\mathrm{P}$ contents (Bühler et al. 2003). In the indirect method, seed $\mathrm{P}$, additionally to the non-labeled fertilizer, dilutes the SA of $\mathrm{P}$ taken up by the plant. The seed $P$ contribution can differ between the fertilized and non-fertilized treatments and can therefore cause an error in the Pdff determined using the indirect method (Eq. 3). In contrast, seed P does not affect the Pdff determined using the direct method because fertilizer $\mathrm{P}$ is labeled (Eq. 1). Thus, seed $\mathrm{P}$ often causes a deviation between Pdff obtained using the indirect and direct method, respectively, particularly at the first and second cuts (Frossard et al. 1994). We estimated seed $\mathrm{P}$ contribution based on the Pdff values obtained for mineral $\mathrm{P}$ and mineral P33 treatments which should be identical. An uptake of $25 \%$ of seed $\mathrm{P}$ (i.e. $0.97 \mathrm{mg}$ seed $\mathrm{P}$ per $\mathrm{kg}$ soil) during the first and $10 \%$ (i.e. $0.39 \mathrm{mg}$ seed $\mathrm{P}$ per $\mathrm{kg}$ soil) during the second growth cycle, respectively, resulted in good adjustments for all soils. From these corrected $\mathrm{P}$ uptake values, corrected SA was calculated for the first and second harvest and used throughout the experiment. The SA of the third and fourth harvest was not corrected for uptake from seed P.

Phosphorus derived from the soil (Pdfs) can be calculated by:

$\operatorname{Pdfs}\left(\mathrm{mg} \mathrm{kg}^{-1}\right.$ soil $)=$ Pupt - Pdff - Pdrf - Pdfseed

Statistical analysis

Statistical analyses were carried out using the GLM procedure of the statistical analysis package SYSTAT 11 (Systat Software Inc., USA). Two-way analyses of variance were run to test the significance of the effects of soils, fertilizer treatments and their interactions. Percentage data was transformed using arcsin-transformation before analysis of variance.

\section{Results}

P status of non-amended and amended soils

Different $\mathrm{P}$ balances induced by the treatments in the field experiment (Table 1) resulted in a gradient of total and available $P$ in soils (Table 2, Fig. 1a). The close relationship between the $\mathrm{P}$ balance and soil $\mathrm{P}$ status has been analyzed in detail by (Oehl et al. 2002). Total $P$ contents were between $560 \mathrm{mg} \mathrm{P} \mathrm{kg}^{-1}$ and $680 \mathrm{mg} \mathrm{P}$ $\mathrm{kg}^{-1}$ soil (Table 2$)$, with the significantly $(P<0.001)$ lowest value in NOFERT and the highest in CONFYM. Inorganic $\mathrm{P}$ ranged from $220 \mathrm{mg} \mathrm{P} \mathrm{kg}^{-1}$ to $330 \mathrm{mg} \mathrm{P}$ $\mathrm{kg}^{-1}$ soil and organic $\mathrm{P}$ from $340 \mathrm{mg} \mathrm{P} \mathrm{kg} \mathrm{Po}^{-1}$ to $380 \mathrm{mg}$ $\mathrm{P} \mathrm{kg}^{-1}$ soil. Total residual $\mathrm{P}$ derived from these total $\mathrm{P}$ contents was $77 \mathrm{mg} \mathrm{P} \mathrm{kg}^{-1}, 66 \mathrm{mg} \mathrm{P} \mathrm{kg}{ }^{-1}, 120 \mathrm{mg} \mathrm{P}$ $\mathrm{kg}^{-1}$ and $96 \mathrm{mg} \mathrm{P} \mathrm{kg}^{-1}$ soil for BIODYN, BIOORG, CONFYM and CONMIN, respectively. The amount of water soluble $\mathrm{P}$ in non-amended soils ranged from $0.05 \mathrm{mg} \mathrm{P} \mathrm{kg}^{-1}$ to $1.9 \mathrm{mg} \mathrm{P} \mathrm{kg}^{-1}$ soil, with minimum in NOFERT and maximum in CONFYM (Fig. 1a).

The addition of $30 \mathrm{mg} \mathrm{P} \mathrm{kg}^{-1}$ soil, either in the form of manure or as mineral $\mathrm{P}$, increased water extractable $\mathrm{P}$ by $1.25-6.6 \mathrm{mg} \mathrm{P} \mathrm{kg}^{-1}$ in all soils (Fig. 1a). The increase was lowest in NOFERT and highest in CONFYM soil. Organically cropped soils and CONFYM, which were regularly fertilized with animal manure in the field, had higher microbial $\mathrm{P}$ contents than NOFERT and CONMIN. Manure P addition increased microbial $\mathrm{P}$ by $1.4-5.2 \mathrm{mg} \mathrm{P} \mathrm{kg}^{-1}$ soil in each soil (Fig. 1b). Microbial $\mathrm{P}$ was not significantly different for mineral $\mathrm{P}$ and zero $\mathrm{P}$ treatments in BIODYN, BIOORG and CONMIN soils. In NOFERT, microbial $\mathrm{P}$ was higher by $3.7 \mathrm{mg} \mathrm{P} \mathrm{kg}^{-1}$ soil in the mineral $\mathrm{P}$ than in the zero $\mathrm{P}$ treatment while the reverse was the case in CONFYM.

Dry matter production and $\mathrm{P}$ uptake by ryegrass

Total dry matter production, average $\mathrm{P}$ concentration and total $\mathrm{P}$ uptake in the four harvests of Italian ryegrass were significantly $(P<0.001)$ affected by soil and fertilizer treatment. With zero $P$, dry matter production increased in the order NOFERT $<$ BIODYN $<$ BIOORG $<$ CONMIN $<$ CONFYM (Fig. 2). Total $\mathrm{P}$ uptake shows the same pattern (Fig. 3). Phosphorus fertilization resulted in an increase of dry matter production for soils from all cropping systems except 
Fig. 1 a, b Soil $\mathrm{P}$ status of amended soils: water extractable $\mathrm{P}$ and microbial $\mathrm{P}$ extractable in water after chloroform fumigation (average and standard error). For explanations of acronyms for soils see Table 1
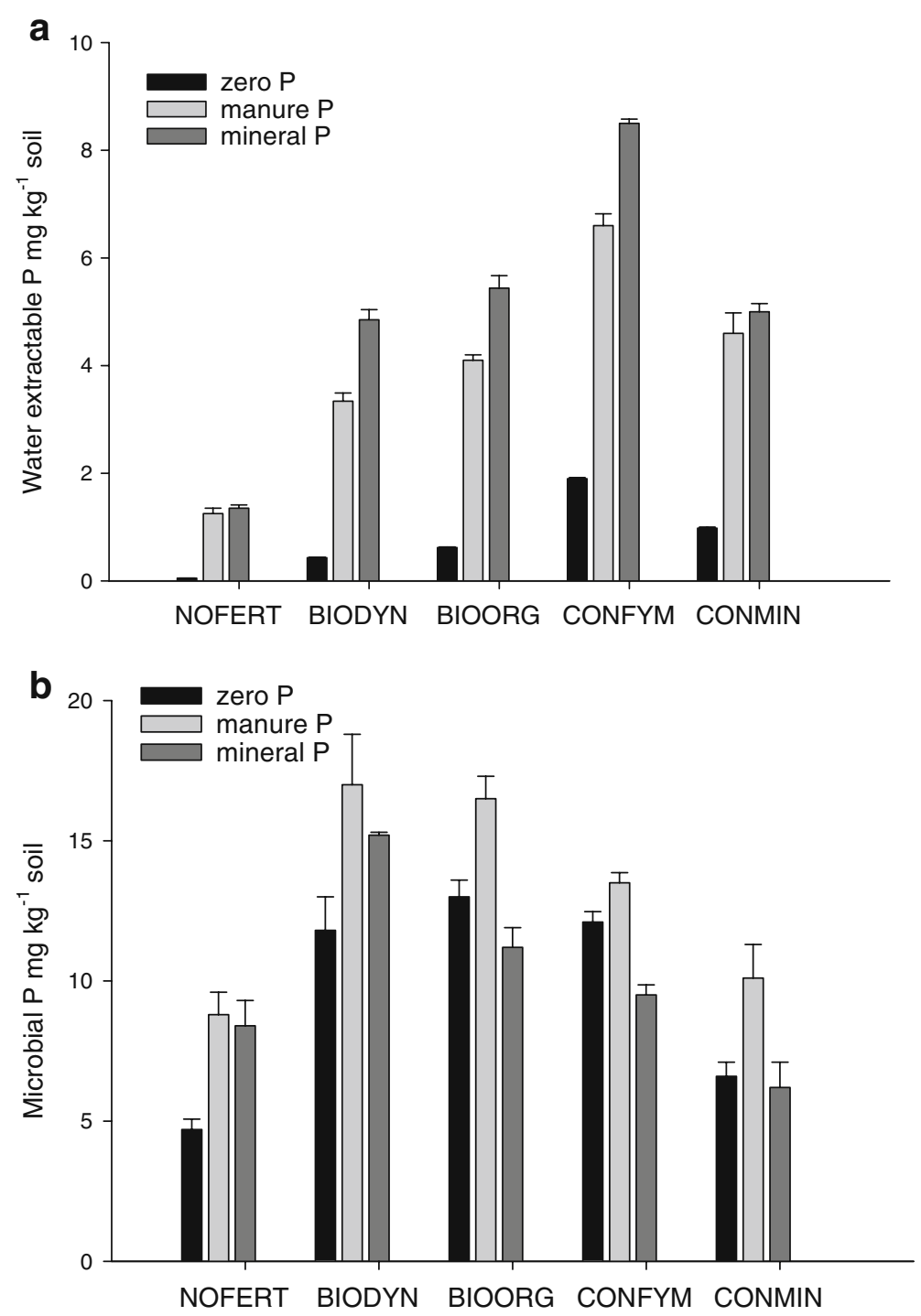

CONFYM (Fig. 2). Phosphorus concentration in shoots (data not shown) and $\mathrm{P}$ uptake increased in all soils following $P$ fertilization. Increases were most pronounced in NOFERT where, for example, $\mathrm{P}$ uptake augmented from $8.7 \mathrm{mg} \mathrm{P} \mathrm{kg}^{-1}$ soil for zero $\mathrm{P}$ to $22 \mathrm{mg} \mathrm{P} \mathrm{kg}^{-1}$ soil for mineral P. Although applied at the same rate, fertilization with animal manure resulted in a lower $\mathrm{P}$ uptake than mineral fertilizer $\mathrm{P}$ application. Total dry matter production and $\mathrm{P}$ uptake did not differ significantly between mineral P and mineral P33 treatments. This is to be expected, because these two treatments only differ in the labeling (indirect vs. direct method).
The time course of cumulative dry matter production and $\mathrm{P}$ uptake from different $\mathrm{P}$ sources is presented for BIODYN and CONFYM soils (Fig. 4). These soils are chosen because they differ in soil $\mathrm{P}$ availability (Fig. 1a) and because results obtained with these soils are representative for soils from the other cropping systems. The response to fertilizer treatments on BIODYN, NOFERT and BIOORG soils was similar where the final dry matter production of ryegrass took the order zero $\mathrm{P}<$ manure $\mathrm{P}<$ mineral $\mathrm{P}$ (Fig. 2). In contrast dry matter production on CONFYM and CONMIN soils took the order manure $\mathrm{P} \leq$ zero $\mathrm{P}<$ mineral $\mathrm{P}$. This different response of the soils became 
Fig. 2 Total shoot dry matter production for four harvests of Italian ryegrass growing on soils from different cropping systems subjected to various fresh $P$ fertilizer treatments (average and standard error). For explanations of acronyms for soils see Table 1

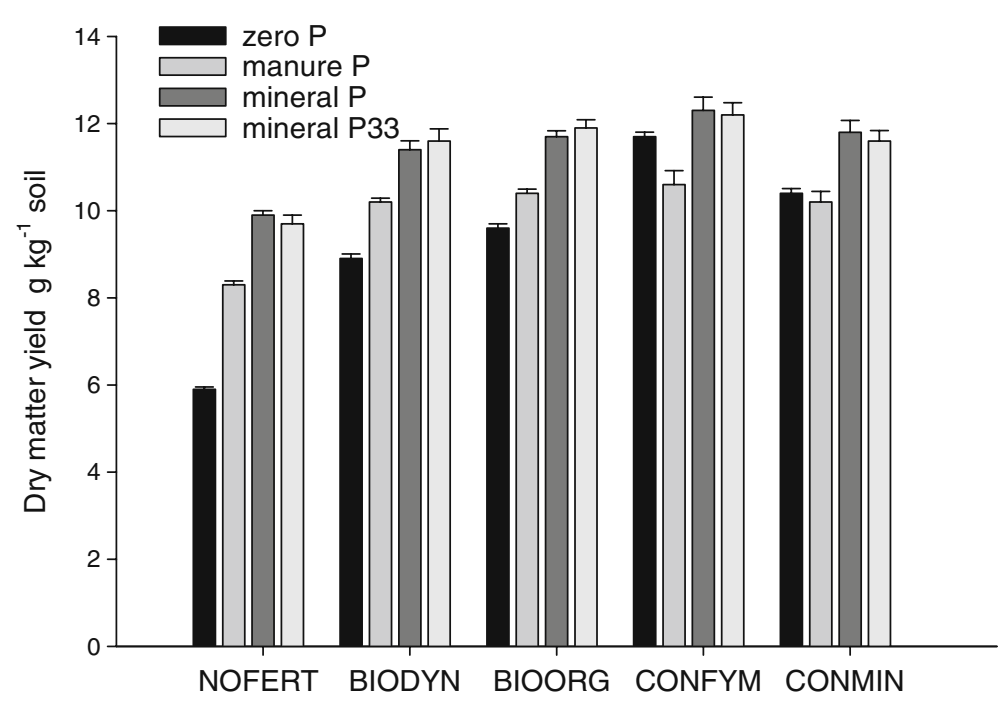

apparent from the first growth cycle (i.e. seeding till first harvest) onwards (Fig. 4a).

$\mathrm{P}$ uptake from fresh fertilizers and residual $\mathrm{P}$

Phosphorus derived from fresh fertilizer was significantly $(P<0.001)$ affected by soil and fertilizer treatment (Fig. 3). Significantly more $P$ was taken up from the mineral fertilizer than the manure. The difference in $\mathrm{P}$ taken up from mineral $\mathrm{P}$ and manure $\mathrm{P}$ ranged from $1.1 \mathrm{mg} \mathrm{P} \mathrm{kg}^{-1}$ soil (NOFERT) to $4 \mathrm{mg} \mathrm{P}$ $\mathrm{kg}^{-1}$ soil (CONFYM). The percentage contribution of fertilizer $\mathrm{P}$ to total $\mathrm{P}$ uptake can be derived from Fig. 3. Fresh fertilizer contributed from 19\% (minimum, manure $\mathrm{P}$ on CONFYM) to 53\% (maximum, mineral $\mathrm{P}$ treatment on NOFERT) of the total $\mathrm{P}$ uptake by ryegrass. The percentage contribution of fresh fertilizer was higher for mineral $\mathrm{P}$ than manure $\mathrm{P}$ for every soil, except for NOFERT were it was 53\% for both fertilizers. The fresh fertilizer contributed more to early than late harvests for both manure and mineral P (Fig. 4c).

The recovery of fresh fertilizer $\mathrm{P}$ in the four harvests ranged from $24 \%$ to $35 \%$ for manure $\mathrm{P}$, and
Fig. 3 Distribution of total $\mathrm{P}$ taken up by four harvests of Italian ryegrass among $\mathrm{P}$ derived from soil, from residual $\mathrm{P}$ and from fresh fertilizer as affected by soils originating from different cropping systems and by fresh $\mathrm{P}$ fertilizer treatment (0P: zero $\mathrm{P}$; $\mathrm{manP}=$ manure $\mathrm{P} ; \min \mathrm{P}=$ water soluble mineral $\mathrm{P}$; $\operatorname{minP} 33={ }^{33} \mathrm{P}$ labeled water soluble mineral P; average and standard error). For explanations of acronyms for soils see Table 1

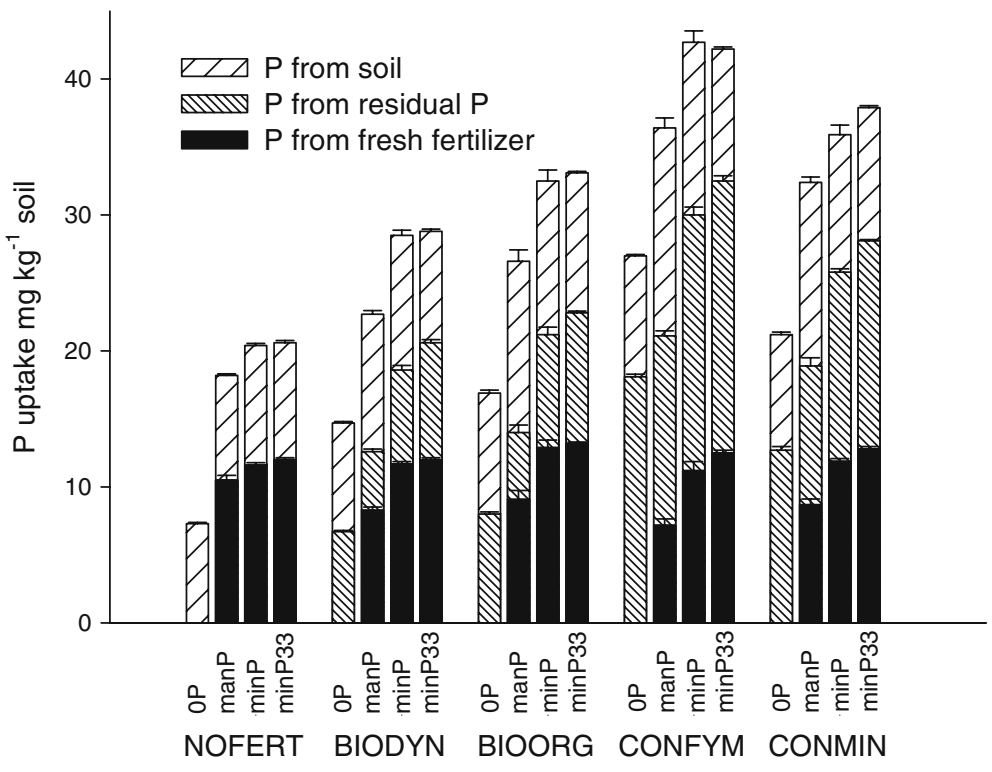



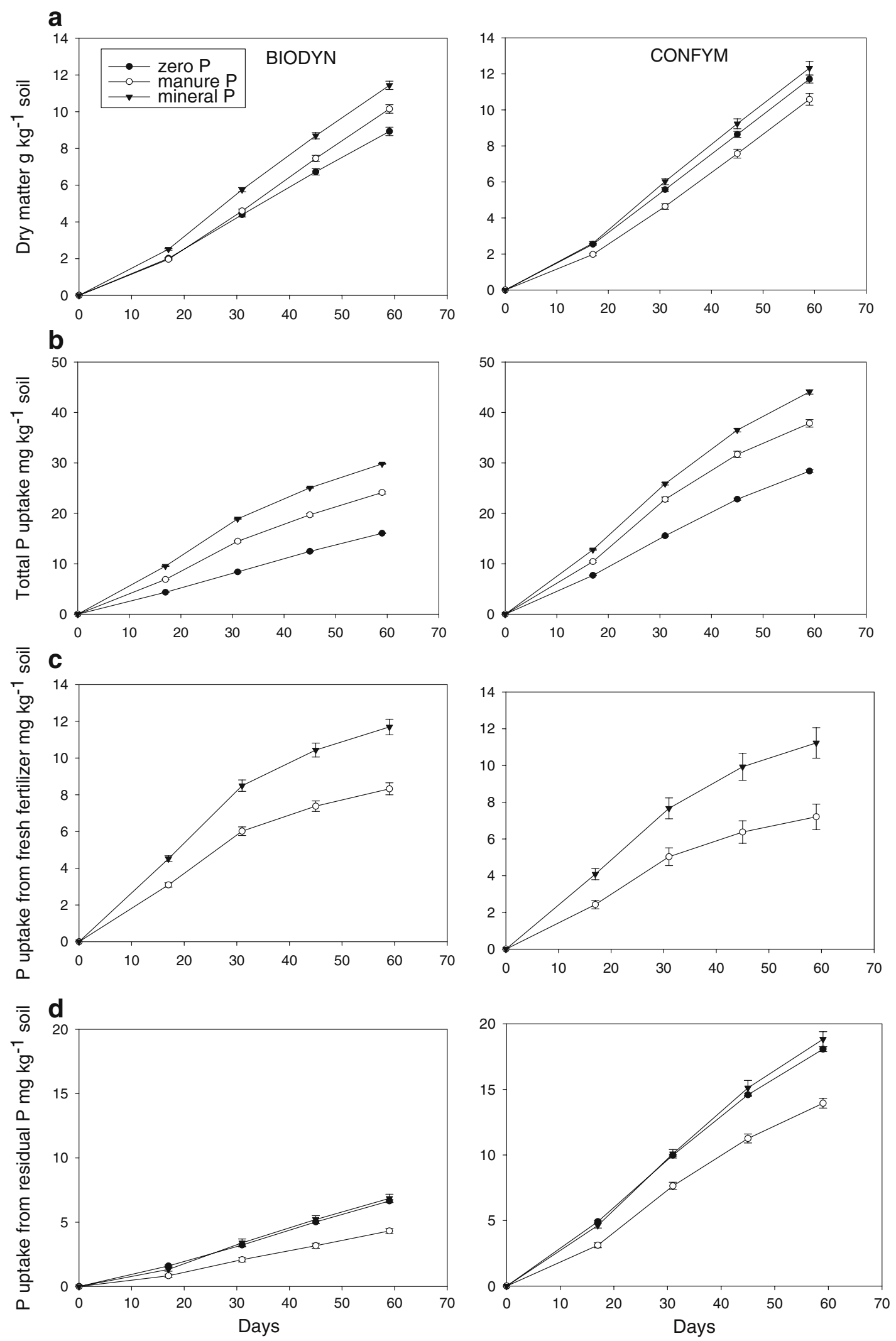
4Fig. 4 Cumulative shoot dry matter yield, total $\mathrm{P}$ uptake, $\mathrm{P}$ uptake from fresh fertilizer (manure or mineral $\mathrm{P}$ ) and $\mathrm{P}$ uptake from residual $\mathrm{P}$ over the entire growth experiment, for the zero $\mathrm{P}$ (filled dot), manure $\mathrm{P}$ (empty dot) and mineral $\mathrm{P}$ (filled triangle) treatment applied to the BIODYN (left) and CONFYM soils (right)

from $37 \%$ to $43 \%$ for mineral P (Fig. 5). On each soil, the recovery of mineral $\mathrm{P}$ was higher than that of manure $\mathrm{P}$. The recoveries of mineral $\mathrm{P}$ obtained with the direct and indirect isotope method were not significantly different.

Also $\mathrm{P}$ derived from residual $\mathrm{P}$ present in FERT soils was significantly $(P<0.001)$ affected by soil and fertilizer treatment (Fig. 3). The differences between soils originating from the different cropping systems were more pronounced for $\mathrm{P}$ taken up from residual $\mathrm{P}$ than from fresh fertilizer. The amount of $\mathrm{P}$ derived from residual $\mathrm{P}$ was higher in the conventional than on the organic soils. For all soils, it was significantly lowest when soils were amended with fresh manure $P$. The addition of mineral $\mathrm{P}$ resulted in a similar or slightly higher residual $\mathrm{P}$ uptake than when no fresh $\mathrm{P}$ was applied. The percentage contribution of residual $\mathrm{P}$ to total $\mathrm{P}$ uptake can be obtained from Fig. 3. It shows that residual $\mathrm{P}$ contributed from $17.5 \%$ (minimum, manure $\mathrm{P}$ treatment on BIOORG) to $63.7 \%$ (maximum, zero $\mathrm{P}$ treatment on CONFYM) of the total $\mathrm{P}$ uptake by ryegrass. For every soil, the percentage contribution of residual $\mathrm{P}$ to total $\mathrm{P}$ uptake was highest for the zero $\mathrm{P}$ and lowest for the manure
$\mathrm{P}$ treatment. Phosphorus derived from residual $\mathrm{P}$ steadily increased after the first growth cycle (Fig. 4d).

The soil delivered between $7.3 \mathrm{mg} \mathrm{P} \mathrm{kg}^{-1}$ and $15.3 \mathrm{mg} \mathrm{P} \mathrm{kg}^{-1}$ soil to total $\mathrm{P}$ uptake (Fig. 3). The percentage contribution of soil $\mathrm{P}$ to total $\mathrm{P}$ uptake was minimum $27 \%$ (mineral $\mathrm{P}$ treatment on CONMIN). The percentage contribution of soil $\mathrm{P}$ to total $\mathrm{P}$ uptake was highest for the zero $P$ treatment on NOFERT, BIODYN and BIOORG soils, while it was highest for the manure P treatment on CONFYM and CONMIN soils.

The recovery of residual $\mathrm{P}$ ranged from $6 \%$ (manure $\mathrm{P}$ on BIODYN) to $17 \%$ (mineral $\mathrm{P}$ on CONFYM) (Fig. 6). For each soil it was lowest when amended with fresh manure $\mathrm{P}$ while it was similar for the zero $\mathrm{P}$ and mineral $\mathrm{P}$ treatments. Residual $\mathrm{P}$ recoveries obtained with the direct mineral P33 labeling tended to be slightly higher than for the indirect mineral $\mathrm{P}$ method (Fig. 6). All four measurements resulted in the same ranking of soils.

\section{Discussion}

Relation between ryegrass productivity, total $\mathrm{P}$ uptake and $\mathrm{N}$ nutrition

Ryegrass produced more dry matter and took up more $\mathrm{P}$ when fertilized with mineral $\mathrm{P}$ than with manure $\mathrm{P}$ (Figs. 2 and 3). This agrees with a higher water
Fig. 5 Recovery of fresh fertilizer in the four harvests of Italian ryegrass as affected by soils originating from different cropping systems (average and standard error). For explanations of acronyms for soils see Table 1

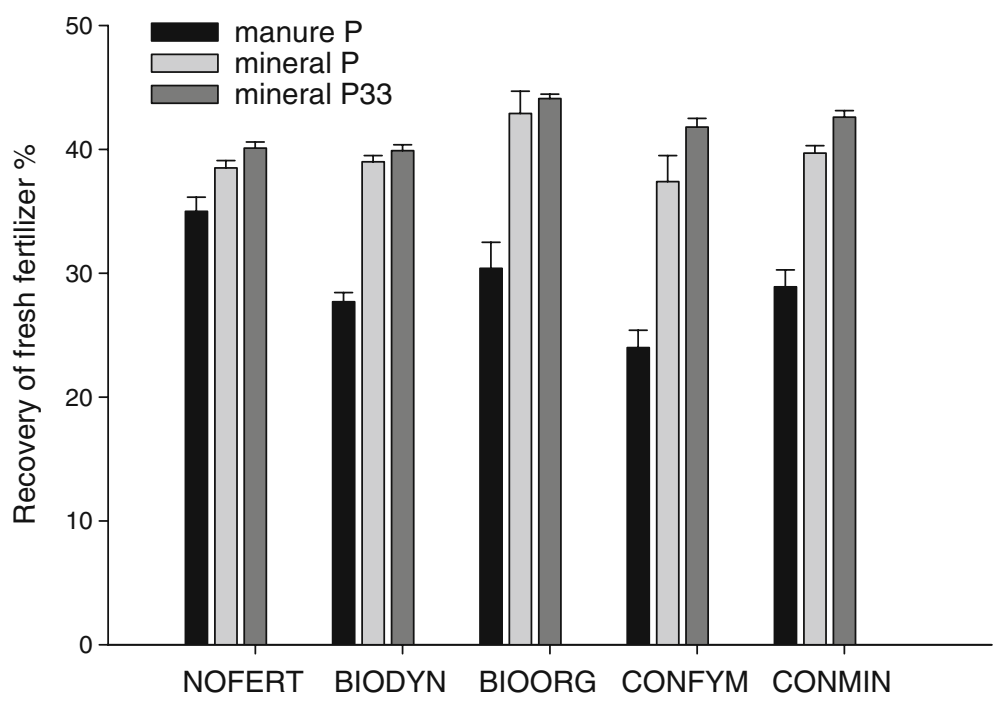


Fig. 6 Recovery of residual $\mathrm{P}$ in four harvests of Italian ryegrass on soils originating from different cropping systems (average and standard error). For explanations of acronyms for soils see Table 1

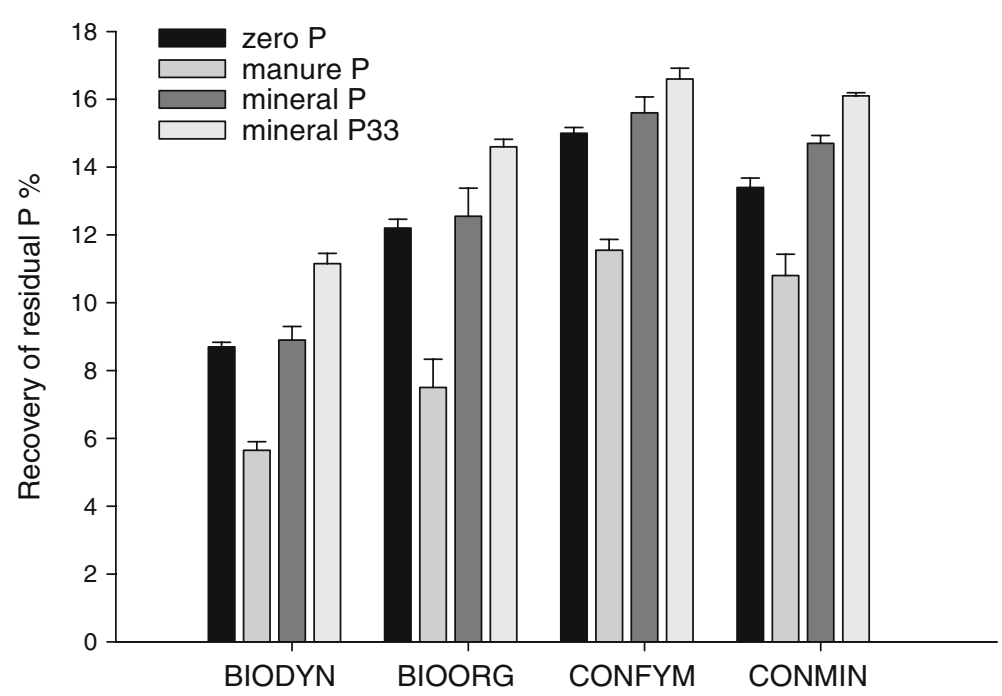

extractable $\mathrm{P}$ content following mineral than manure $P$ addition on most soils (Fig. 1a). However, on CONFYM and CONMIN soils, ryegrass produced even less dry matter when fertilized with manure than for the zero P treatment. Manure P clearly increased available $\mathrm{P}$ over zero $\mathrm{P}$ in all soils (Fig. 1a). Also, the average $\mathrm{P}$ concentrations in ryegrass for four harvests were $3.6 \mathrm{mg} \mathrm{P} \mathrm{g}^{-1}$ and $3.3 \mathrm{mg} \mathrm{P} \mathrm{g}^{-1}$ dry matter for the manure $\mathrm{P}$ treatment of CONFYM and CONMIN soils, respectively. This is the range in which $\mathrm{P}$ does not limit ryegrass growth (Bergmann 1993). Therefore, an additional factor other than $\mathrm{P}$ determined plant response to the manure treatment. At the first harvest, average nitrogen $(\mathrm{N})$ concentration in ryegrass was $25 \mathrm{mg} \mathrm{N} \mathrm{g}^{-1}$ dry matter for the manure P treatment while it was $36 \mathrm{mg} \mathrm{N} \mathrm{g}^{-1}$ and $44 \mathrm{mg} \mathrm{N} \mathrm{g}^{-1}$ dry matter for the mineral $\mathrm{P}$ and zero $\mathrm{P}$ treatments, respectively. In later harvests, differences in $\mathrm{N}$ concentrations in the different $\mathrm{P}$ fertilizer treatments became less, with average $\mathrm{N}$ concentrations of $34 \mathrm{mg} \mathrm{N} \mathrm{g}^{-1}$, $30 \mathrm{mg} \mathrm{N} \mathrm{g}^{-1}$ and $29 \mathrm{mg} \mathrm{N} \mathrm{g}^{-1}$ dry matter for zeroP, manure $\mathrm{P}$ and mineral $\mathrm{P}$, respectively. Thus $\mathrm{N}$ may have limited dry matter production and $\mathrm{P}$ uptake in the manure $\mathrm{P}$ treatment during the first growth cycle because $\mathrm{N}$ concentration in ryegrass was below the critical concentration of $30 \mathrm{mg} \mathrm{N} \mathrm{g}^{-1}$ dry matter proposed by (Bergmann 1993) for Lolium spp. In total we added $430 \mathrm{mg} \mathrm{N} \mathrm{kg}^{-1}$ soil distributed over all growth cycles. This amount exceeded total $\mathrm{N}$ uptake by the four harvests, which was at most $360 \mathrm{mg} \mathrm{N} \mathrm{kg}^{-1}$ soil. In the manure $\mathrm{P}$ treatment, $62 \mathrm{mg} \mathrm{N} \mathrm{kg}^{-1}$ soil of the $430 \mathrm{mg} \mathrm{N} \mathrm{kg}^{-1}$ soil was added in form of manure
(Table 3). Only a fraction of manure $\mathrm{N}$ is plant available, as shown by (Langmeier et al. 2002) where $18 \%$ of manure $\mathrm{N}$ (applied with the same feces as used in our experiment) was recovered in six harvests of Italian ryegrass while recovery was $75 \%$ for mineral $\mathrm{N}$ fertilizer. Manure addition not only induced microbial $\mathrm{P}$ immobilization (Fig. 1b), but also microbial $\mathrm{N}$ immobilization. Using the fumigation extraction method of (Vance et al. 1987) without correction for incomplete cell lysis, we measured increases in microbial $\mathrm{N}$ ranging from $2 \mathrm{mg} \mathrm{N} \mathrm{kg}^{-1}$ to $10 \mathrm{mg} \mathrm{N} \mathrm{kg}^{-1}$ soil in our incubation study. Thus, testing manure $\mathrm{P}$ would have required a higher $\mathrm{N}$ addition to exclude any $\mathrm{N}$ limitation.

\section{Uptake of freshly applied P fertilizers}

More mineral than manure $\mathrm{P}$ was recovered in ryegrass (Fig. 5). Despite the fact that $\mathrm{N}$ limitation may have limited manure $\mathrm{P}$ uptake during the first growth cycle, the lower $\mathrm{P}$ uptake from manure than mineral $\mathrm{P}$ accords with the soil water extractable $\mathrm{P}$ content indicating lower $\mathrm{P}$ availability in manure $\mathrm{P}$ than mineral $P$ treatments a few days after fertilizer addition (Fig. 1a). Mineral $P$ was added in the form of water-soluble diammonium phosphate, while only $75 \%$ of manure was in inorganic form and less than $60 \%$ of this was immediately plant available $\mathrm{P}$ (Table 3). Recovery of manure P was also lower than for mineral $\mathrm{P}$ in a field study with corn (Zea mays L.) and was dependent on the rate of manure application (Eghball and Power 1999). Plant P uptake was also 
lower from the organic than mineral $\mathrm{P}$ source in a study by (McLaughlin et al. 1988) where wheat plants recovered about $12 \%$ of mineral fertilizer $\mathrm{P}$ but only $5 \%$ of $\mathrm{P}$ applied with legume residues.

The soil affected $\mathrm{P}$ recovery in ryegrass more for manure $\mathrm{P}$ than for mineral $\mathrm{P}$ (Figs. 3 and 5). The recovery of manure $\mathrm{P}$ was highest on NOFERT with the lowest soil-available $\mathrm{P}$ contents and low microbial activity. In contrast, recovery of manure $\mathrm{P}$ was lowest on CONFYM with the highest soil-available $\mathrm{P}$ and average microbial activity. Manure $\mathrm{P}$ recovery was significantly $(P<0.01)$ higher on the BIOORG than the CONFYM soil, but there was no systematic difference in $\mathrm{P}$ recovery by ryegrass on soils that were under organic vs. conventional cropping for a long period. The $\mathrm{P}$ derived from manure and manure $P$ recovery did not differ significantly on BIODYN, BIOORG and CONMIN soils which had similar available $\mathrm{P}$ contents but which differed in microbial activity (Fig. 1a, b). Immobilization of manure $P$ was higher in the BIODYN and BIOORG soils than in the CONMIN soil (Fig. 1b). However, a previous study using the same soils showed that organic P mineralization was higher in BIOORG and BIODYN soils that in CONMIN (Oehl et al. 2004). Thus, uptake of manure $\mathrm{P}$ is higher the lower the initial soil available $\mathrm{P}$, as previously shown for mineral fertilizer $\mathrm{P}$ (Gallet et al. 2003). Microbial activity seems of subordinate importance in the recovery of manure $\mathrm{P}$ in plants, suggesting that higher microbial $\mathrm{P}$ immobilization following manure addition was compensated by higher $\mathrm{P}$ mineralization in both organic than the CONMIN soil.

Soils under organic cropping often have lower available $\mathrm{P}$ contents than soils under conventional cropping (Cornish 2009; Løes and Øgaard 2001). In our study, water extractable $\mathrm{P}$ in soils of the zero $\mathrm{P}$ treatment, i.e. at the $\mathrm{P}$ status of soils in the field, was less than $1 \mathrm{mg} \mathrm{P} \mathrm{kg}^{-1}$ in NOFERT, BIODYN and BIOORG soils. If water soluble $\mathrm{P}$ is below $1 \mathrm{mg} \mathrm{P}$ $\mathrm{kg}^{-1}$ then $\mathrm{P}$ becomes growth limiting and $\mathrm{P}$ additions increase crop production (Frossard et al. 2004). Available P contents below (NOFERT, BIODYN) or close to the critical limit (BIOORG) were confirmed by amounts of isotopically exchangeable $\mathrm{P}$ (data not shown). Thus, through their lower available P content organic soils have the potential of greater fresh manure recovery, i.e., greater use efficiency, but care must be taken that $\mathrm{P}$ does not become a factor limiting crop production.
Uptake of residual $\mathrm{P}$

The residual $\mathrm{P}$ recovery determined either in the presence of fresh $\mathrm{P}$ amendments (manure $\mathrm{P}$ or mineral $\mathrm{P}$ ), or in the absence of fresh $\mathrm{P}$ additions, gives the same ranking for the soils (Fig. 6). Residual P recovery was always lowest on BIODYN and highest on conventionally cultivated soils. Residual P is composed of plant-available soil $\mathrm{P}$ depleted in the NOFERT soil but not in the FERT soils, and of residual fertilizer $\mathrm{P}$ remaining in the FERT soils. Because CONFYM also received $\mathrm{P}$ in the form of animal manure, the results do not allow a clear conclusion that residual animal manure $\mathrm{P}$ is less available than residual mineral $\mathrm{P}$. Organically cultivated soils tend to have a larger proportion of residual $\mathrm{P}$ in organic forms (Table 2). About $20-25 \%$ of the $\mathrm{P}$ applied with the manure in the same field experiment is in organic form (Oberson et al. 1993). Increases in soil organic $P$ have been observed in soils receiving manure for over 100 years (Motavalli and Miles 2002). At similar residual P contents in BIODYN and BIOORG soils, recovery of residual $\mathrm{P}$ was lower for BIODYN than BIOORG. This suggests that composting and aerated slurry treatment on the bio-dynamic farms might result in more stable organic compounds which remain in the soil. This is underlined by the finding that the soil organic $\mathrm{C}$ content in the plough layer of BIODYN was maintained while soil organic $C$ decreased for all other systems (Fliessbach et al. 2007). To our knowledge the effect of manure composting on $\mathrm{P}$ speciation has hardly been investigated. (Toor et al. 2006), using sequential chemical extraction, report that dairy manure composts contain significantly less water extractable inorganic $\mathrm{P}$ than non-composted dairy manure, but more of less soluble inorganic $\mathrm{P}$ forms (particularly $\mathrm{HCl}$ extractable $\mathrm{Ca}$ bound $\mathrm{P}$ ) and less organic $\mathrm{P}$. (Traoré et al. 1999) found a decrease in water extractable inorganic $\mathrm{P}$ and an increase in $\mathrm{HCl}$ extractable inorganic $\mathrm{P}$ during the composting of three types of organic wastes. Thus, residual organic and inorganic fertilizer $\mathrm{P}$ contained in BIODYN might be of low availability to crops. Finally, as a result of lower $\mathrm{P}$ balances (Table 1), organically cultivated soils contained less total P (Table 2; (Oehl et al. 2002)) and in turn, less residual $\mathrm{P}$ than conventionally cultivated soils. The more residual $\mathrm{P}$ gets depleted, the less available the remainder is likely to be. As suggested by the distribution of $\mathrm{P}$ fractions in the same 
soils (Oberson et al. 1993), the higher the P deficit in the $\mathrm{P}$ balance, the lower the contents of labile $\left(\mathrm{NaHCO}_{3}\right.$-extractable) and moderately labile $(\mathrm{NaOH}-$ extractable) inorganic $\mathrm{P}$ fractions, while less soluble $\mathrm{P}$ forms remained unaffected.

(Gallet et al. 2003) studied residual P uptake by ryegrass on soils taken in three field experiments, fertilized with triple superphosphate, for at least 9 years. Their results correspond to recoveries ranging from $7 \%$ to $11 \%$ (calculated from (Gallet et al. 2003)). This is in the range of the recoveries found in our study. However, in contrast to our results, for each soil studied by (Gallet et al. 2003), residual P recovery was greater when ryegrass was fertilized with diammonium phosphate during the pot experiment than when no fresh fertilizer was applied, suggesting an interaction between fresh fertilizer $\mathrm{P}$ and residual $\mathrm{P}$.

Methodological considerations

\section{Direct and indirect isotope method to determine uptake from fresh fertilizer}

From the total P uptake (Fig. 3) an apparent fresh fertilizer $P$ recovery can be calculated by the difference method ( $\mathrm{P}$ uptake in fertilised treatment $-\mathrm{P}$ uptake in zero $\mathrm{P}$ treatment)/total $\mathrm{P}$ applied $\times 100$. The apparent recovery on NOFERT, BIODYN, BIOORG, CONFYM and CONMIN soils was 36\%, 27\%, 32\%, 31\% and $38 \%$ for manure $\mathrm{P}$, and $43 \%, 46 \%, 52 \%, 52 \%$ and $49 \%$ for mineral P. For manure P, the apparent recoveries and recoveries obtained with the isotope technique were nearly the same for NOFERT and both organically cultivated soils. On conventionally cultivated soils amended with manure $P$, as well as for all soils amended with mineral $\mathrm{P}$ or mineral $\mathrm{P} 33$, the apparent recoveries were by $7 \%$ to $15 \%$ higher than the recovery obtained with the isotope method. Higher recoveries obtained with the difference rather than the isotope method suggest that fertilizer addition increased the $\mathrm{P}$ uptake from soil. This phenomenon is known from $\mathrm{N}$ studies when using ${ }^{15} \mathrm{~N}$ labeled fertilizers and is called "added nitrogen interaction" (Jenkinson et al. 1985). The sum of $\mathrm{P}$ derived from residual $\mathrm{P}$ and from soil presents soil derived $\mathrm{P}$ when the concept of added nutrient interactions is applied to our experiment. This sum was increased by 1.5 (NOFERT) to $4.4 \mathrm{mg} \mathrm{P} \mathrm{kg}^{-1}$ soil (CONFYM) in mineral $\mathrm{P}$ compared with zero $\mathrm{P}$
(Fig. 3). Manure $\mathrm{P}$ addition increased this sum by 2.2 (CONFYM) and $2.6 \mathrm{mg} \mathrm{kg}^{-1}$ (CONMIN) over zero P while on NOFERT, BIODYN and BIOORG soils it remained almost unaffected. Interactions of freshly applied P on P uptake from soil and residual P (called hereafter added $\mathrm{P}$ interactions) were low but seemed more important for mineral $\mathrm{P}$ than manure $\mathrm{P}$.

Added $\mathrm{P}$ interactions can be real, caused by e.g. increased soil $\mathrm{P}$ uptake resulting from greater soil exploration by roots after mineral $\mathrm{P}$ fertilizer addition (Morel and Fardeau 1989a). They may also be apparent because the assumptions underlying isotope dilution principles in the indirect method have not been fully met (Hood 2001). For P, these assumptions are that soil available $\mathrm{P}$ is homogenously labeled and that any dilution of SA in the fertilized plant is due to uptake from non-labeled fertilizer. However, for harvests 3 and 4, which were not affected by seed $P$ correction, mineral $\mathrm{P}$ results obtained with the indirect isotope method were confirmed by the direct method: The overall average proportion of $\mathrm{P}$ derived from fresh fertilizer was $36 \%$ for the direct and $32 \%$ for the indirect method. Both approaches resulted in the same rankings of soils.

For manure $\mathrm{P}$ we have no direct isotope method check. The above comparison with the apparent recovery obtained by the difference method suggests that added $\mathrm{P}$ interactions were less important for manure than for mineral P. However, manure $\mathrm{P}$ addition affected microbial biomass more than mineral $\mathrm{P}$ addition (Fig. 1b). Increased microbial activity could increase the mineralization of soil organic $\mathrm{P}$ that was not labeled (Oehl et al. 2004). This process would, in addition to the added non-labeled manure $\mathrm{P}$, dilute SA in the soil solution. This would result in an overestimation of $P$ uptake from manure.

Thus, testing the $\mathrm{P}$ uptake from an organic $\mathrm{P}$ source by the indirect isotope method would require the label to be added to the soil a long time before starting the growth trial, so that the labeling of soil $\mathrm{P}$ also involves biotic processes and organic P forms. In ${ }^{15} \mathrm{~N}$ studies, where microbial processes and organic matter dominate nutrient dynamics, pre-labeling the soil several months in advance has proven necessary and useful (Hood 2001). When working with $\mathrm{P}$ radioisotopes, their short half-life time renders such an approach impossible. Still, the time between labeling soil $\mathrm{P}$ and the addition of the fertilizer should 
be maximized. When the aim is to test $\mathrm{P}$ uptake from an organic fertilizer, it may also be worthwhile to test an approach with organic $\mathrm{C}$ addition at soil $\mathrm{P}$ labeling, to stimulate the microbial growth and labeling of microbial P.

\section{Indirect method to determine uptake from residual $P$}

Uptake from residual $\mathrm{P}$ can be estimated only by indirect isotope dilution. This approach is less affected by added $\mathrm{P}$ interactions than the indirect method of assessing uptake from fresh fertilizer because residual $\mathrm{P}$ was in contact with the soil for years. In this respect the residual $\mathrm{P}$ uptake estimated from the zero $\mathrm{P}$ treatments can be regarded as the most reliable (Eq. 5). Residual P recoveries obtained with the zero $\mathrm{P}$ treatments were also close to apparent recoveries of residual $\mathrm{P}$ obtained with the difference method where residual $\mathrm{P}$ uptake is calculated as difference in P uptake between FERT and NOFERT soils divided by total residual $\mathrm{P}$. These recoveries were $9 \%, 15 \%, 16 \%$, and $15 \%$, respectively, for BIODYN, BIOORG, CONFYM and CONMIN soils. If residual $\mathrm{P}$ uptake is estimated using isotope dilution in the presence of fresh fertilizers then bias may arise when added $P$ interactions differ between the NOFERT reference and FERT soils. As mentioned previously, manure $\mathrm{P}$ addition had the greatest impact on microbial activity. Microbial $\mathrm{P}$ immobilization (Fig. 1b) and re-mineralization differ between the studied soils (Oehl et al. 2001). Thus the impact on the SA of soil solution P, and in turn on the SA in the plant, depends on the soil. In conclusion, residual $\mathrm{P}$ uptake should best be estimated without fresh fertilizer addition, particularly when freshly added organic P sources are not present.

\section{Conclusions}

Fresh manure increased water extractable $\mathrm{P}$ and $\mathrm{P}$ uptake by ryegrass on all soils but to a lesser degree than with the addition of the same $\mathrm{P}$ amount in the form of water-soluble mineral $\mathrm{P}$. The recovery of manure $\mathrm{P}$ in four harvests of ryegrass ranged from $24 \%$ to $35 \%$, while it was $37 \%$ to $43 \%$ for mineral $\mathrm{P}$. The recovery of manure $\mathrm{P}$ was highest on NOFERT soil with the lowest available P content and lowest microbial $\mathrm{P}$, while differences between organically and conventionally cultivated soils were less pronounced. Thus, uptake of fresh $\mathrm{P}$ by plants is mainly affected by fertilizer characteristics and the soil available P status. Greater soil microbial activity in the organic as opposed to the conventional cropped soils did not increase $\mathrm{P}$ use efficiency. However, because uptake of fertilizer $\mathrm{P}$ is higher at lower soil available $\mathrm{P}$, organic cropping systems have the potential of higher use efficiency. Still, care must be taken that their soil available P contents do not drop into a crop growth limiting range.

Recovery of residual P was lowest on the BIODYN and highest on the CONFYM soil. Because CONFYM also received $\mathrm{P}$ in the form of animal manure, the results do not allow a clear conclusion as to whether residual animal manure $\mathrm{P}$ is more or less available than mineral P. The organically cultivated soils contained less residual $\mathrm{P}$. Thus greater depletion of residual $\mathrm{P}$ may have left recalcitrant $\mathrm{P}$ forms. It would be interesting to compare the uptake of residual $\mathrm{P}$ in field experiments with soils containing similar residual $\mathrm{P}$ amounts in mineral fertilizer and manure treatments.

The indirect isotope dilution technique is useful to assess the uptake of fresh and residual manure $P$ by plants, but care must be taken to minimize added $\mathrm{P}$ interactions. Uptake from fresh manure $\mathrm{P}$ was probably overestimated due to the mineralization on non-labeled soil organic $\mathrm{P}$. When determining the plant $\mathrm{P}$ uptake from an organic $\mathrm{P}$ source with the indirect method, an early labeling of soil available $\mathrm{P}$ is recommended. Assessing the uptake of residual $\mathrm{P}$ seems most accurate when no fresh fertilizer is added.

Acknowledgements We gratefully acknowledge L. Gunst (ART) for providing data records on the field experiment. We warmly thank T. Flura and T. Rösch (ETH Zurich) for assistance in the analytical work and Catherine Palmer (ETH Zurich) for checking the English. We gratefully acknowledge Simone Nanzer (ETH Zurich) and two anonymous reviewers for her helpful comments on our script.

\section{References}

Barrow N J (1980) Evaluation and utilization of residual phosphorus in soils. In: The role of phosphorus in agriculture. pp 333-359. ASA-CSSA-SSSA, Madison, Wisconsin 
Bergmann W (1993) Ernährungsstörungen bei Kulturpflanzen. Gustav Fischer Verlag, Jena und Stuttgart

Besson JM, Niggli U (1991) DOK-Versuch: vergleichende Langzeit-Untersuchungen in den drei Anbausystemen biologisch-dynamisch, organisch-biologisch und konventionell: 1. Konzeption des DOK-Versuches: 1. und 2. Fruchtfolgeperiode. Schweiz Landw Forschung 31:79-109

Bühler S, Oberson A, Sinaj S, Friesen DK, Frossard E (2003) Isotope methods for assessing plant available phosphorus in acid tropical soils. Europ J Soil Sci 54:605-616

Cornish PS (2009) Phosphorus management on extensive organic and low-input farms. Crop \& Pasture Science 60:105-115

Eghball B, Power JF (1999) Phosphorus- and nitrogen-based manure and compost applications: corn production and soil phosphorus. Soil Sci Soc Am J 63:895-901

Fardeau JC (1993) Le Phosphore assimilable du sol: sa représentation par un modèle fonctionnel a plusieurs compartiments. Agronomie 13:317-331

Fardeau JC (1996) Dynamics of phosphate in soils: an isotopic outlook. Fert Res 45:91-100

Fliessbach A, Oberholzer HR, Gunst L, Mäder P (2007) Soil organic matter and biological soil quality indicators after 21 years of organic and conventional farming. Agric Ecosyst Environ 118:273-284

Frossard E, Fardeau JC, Brossard M, Morel JL (1994) Soil isotopically exchangeable phosphorus: a comparison between $\mathrm{E}$ and L values. Soil Sci Soc Am J 58:846-851

Frossard E, Sinaj S, Zhang LM, Morel JL (1996) Effect of soil and sludge properties on the fate of sludge phosphorus in soil-plant systems. Soil Sci Soc Am J 60:1248-1253

Frossard E, Julien P, Neyroud J-A, Sinaj S (2004) Phosphor in Böden-Standortbestimmung Schweiz. p. 174. Bundesamt für Umwelt, Wald und Landschaft, Bern

Gallet A, Flisch R, Ryser JP, Nösberger J, Frossard E, Sinaj S (2003) Uptake of residual phosphate and freshly applied diammonium phosphate by Lolium perenne and Trifolium repens. J Plant Nutr Soil Sci 166:557-567

Guggenberger G, Christensen BT, Rubæk GH (2000) Isolation and characterization of labile organic phosphorus pools in soils from the Askov long-term field experiments. J Plant Nutr Soil Sci 163:151-155

Hooda PS, Truesdale VW, Edwards AC, Withers PJA, Aitken MN, Miller A, Rendell AR (2001) Manuring and fertilization effects on phosphorus accumulation in soils and potential environmental implications. Adv Environ Res 5:13-21

Hood R (2001) Evaluation of a new approach to the nitrogen15 isotope dilution technique, to estimate crop $\mathrm{N}$ uptake from organic residues in the field. Biol Fertil Soils 34:156161

Jenkinson DS, Fox RH, Rayner JH (1985) Interactions between fertilizer nitrogen and soil nitrogen - the so-called priming effect. J Soil Sci 36:425-444

Langmeier M, Frossard E, Kreuzer M, Mäder P, Dubois D, Oberson A (2002) Nitrogen fertilizer value of cattle manure applied on soils originating from organic and conventional farming systems. Agronomie 22:789-800
Leifeld J, Reiser R, Oberholzer HR (2009) Consequences of conventional versus organic farming on soil carbon: results from a 27-year field experiment. Agron J 101: 1204-1218

Løes AK, Øgaard AF (2001) Long-term changes in extractable soil phosphorus (P) in organic dairy farming systems. Plant Soil 237:321-332

Mäder P, Fliessbach A, Dubois D, Gunst L, Fried P, Niggli U (2002) Soil fertility and biodiversity in organic farming. Science 296:1694-1697

McLaughlin MJ, Alston AM, Martin JK (1988) Phosphorus cycling in wheat-pasture rotations I The source of phosphorus taken up by wheat. Aust J Soil Res 26:323-331

Motavalli PP, Miles RJ (2002) Soil phosphorus fractions after 111 years of animal manure and fertilizer application. Biol Fertil Soils 36:35-42

Morel C, Fardeau JC (1989a) The uptake by crops of fresh and residual phosphatic fertilizers by simultaneous measurements with 32P and 33P. Appl Radiat Isot 40:273-278

Morel C, Fardeau JC (1989b) Native soil and fresh fertilizer phosphorus uptake as affected by rate of application and $\mathrm{P}$ fertilizers. Plant Soil 115:123-128

Murphy J, Riley JP (1962) A modified single solution method for the determination of phosphate in natural waters. Anal Chim Acta 27:31-36

Oberson A, Frossard E (2005) Phosphorus management for organic agriculture. In: Sims JT, Sharpley AN (eds) Phosphorus: agriculture and the environment. ASA, CSSA and SSSA, Madison, Wisconsin, USA, pp 761-779

Oberson A, Fardeau JC, Besson JM, Sticher H (1993) Soil phosphorus dynamics in cropping systems managed according to conventional and biological agricultural methods. Biol Fertil Soils 16:111-117

Oehl F, Oberson A, Probst M, Fliessbach A, Roth HR, Frossard E (2001) Kinetics of microbial phosphorus uptake in cultivated soils. Biol Fertil Soils 34:31-41

Oehl F, Oberson A, Tagmann HU, Besson JM, Dubois D, Mäder P, Roth HR, Frossard E (2002) Phosphorus budget and phosphorus availability in soils under organic and conventional farming. Nutr Cycl Agroecosys 62:2535

Oehl F, Frossard E, Fliessbach A, Dubois D, Oberson A (2004) Basal organic phosphorus mineralization in soils under different farming systems. Soil Biol Biochem 36:667675

Saunders WMH, Williams EG (1955) Observations on the determination of total organic phosphorus in soils. J Soil Sci 6:247-267

Sinaj S, Traoré O, Frossard E (2002) Effect of compost and soil properties on the availability of compost phosphate for white clover (Trifolium repens L.). Nutr Cycl Agroecosys 62:89-102

Stewart WM, Hammond LL, van Kauwenbergh SJ (2005) Phosphorus as a natural resource. In Phosphorus: agriculture and the environment. Eds. JT Sims and AN Sharpley. pp 3-22. ASA, CSSA and SSSA. Madison, Wisconsin, USA 
Toor GS, Hunger S, Peak JD, Sims JT, Sparks DL, Donald LS (2006) Advances in the characterization of phosphorus in organic wastes: environmental and agronomic applications. Adv Agron 89:1-72

Traoré O, Sinaj S, Frossard E, Van De Kerkhove JM (1999) Effect of composting time on phosphate exchangeability. Nutr Cycl Agroecosys 55:123-131

Sharpley AN, Smith SJ, Stewart BA, Mathers AC (1984) Forms of phosphorus in soil receiving cattle feedlot waste. J Environ Qual 13:211-215
USDA 1999 Soil Taxonomy-A basic system of soil classification for making and interpreting soil surveys. United States Department of Agriculture

Vance ED, Brookes PC, Jenkinson DS (1987) An extraction method for measuring soil microbial biomass C. Soil Biol Biochem 19:703-707

Wichern F, Müller T, Joergensen RG, Buerkert A (2004) Effects of manure quality and application forms on soil $\mathrm{C}$ and $\mathrm{N}$ turnover of a subtropical oasis soil under laboratory conditions. Biol Fertil Soils 39:165-171 